\title{
The Marginal Product of Capital: A Persistent International Puzzle
}

\author{
ROBERT S. CHIRINKO \\ DEBDULAL MALLICK
}

\author{
CESIFO WORKING PAPER NO. 2399 \\ CATEGORY 5: Fiscal Policy, MaCROECONOMICS AND GROWTH \\ SEPTEMBER 2008
}

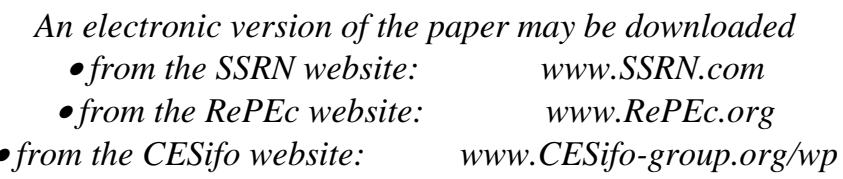




\title{
The Marginal Product of Capital: A Persistent International Puzzle
}

\begin{abstract}
Large and sustained differences in marginal products of capital (MPKs) across countries are sharply at odds with the core implications of the neoclassical framework. Lucas (1990) and many subsequent studies have examined reasons for this MPK differential. In a recent contribution, Caselli and Feyrer (2007) take the ground out from under this debate by reconsidering measurement issues and concluding that the MPK differential vanishes. Despite Caselli and Feyrer's important advances in measurement, the international MPK puzzle persists. We show that the measurement of MPKs in their framework is substantially affected by adjustment costs in the accumulation of capital. With the proper technology and a plausible parameterization of adjustment costs, the MPK in poor countries is much higher than the MPK in rich countries. Why capital flows do not eliminate the MPK differential remains a persistent international puzzle. We examine the quantitative importance of financial frictions, relative prices, and adjustment costs in accounting for the MPK differential and document that adjustment costs provide the leading explanation.
\end{abstract}

JEL Code: O11, O16, E22.

Keywords: marginal product of capital, adjustment costs, macroeconomic analysis of economic development, international capital flows.

\author{
Robert S. Chirinko \\ Department of Finance \\ University of Illinois at Chicago \\ 2333 University Hall \\ 601 South Morgan (MC 168) \\ USA - Chicago, Illinois 60607-7121 \\ Chirinko@uic.edu
}

\author{
Debdulal Mallick \\ School of Accounting, Economics, and \\ Finance at Deakin University \\ Burwood, Victoria 3125 \\ Australia \\ Debdulal.Mallick@Deakin.edu.au
}

We gratefully acknowledge helpful comments from Andrew Abel, Francesco Caselli, Russell Cooper, and Carolina Villegas-Sanchez and the detailed comments on a prior draft from Shomu Banerjee. Chirinko thanks the European University Institute for providing an excellent environment in which to complete this research. All errors and omissions are the sole responsibility of the authors, and the conclusions do not necessarily reflect the views of the organizations with which they are associated. 


\section{The Marginal Product of Capital:}

\section{A Persistent International Puzzle}

\section{Table of Contents}

I. Introduction

II. Measuring the Marginal Product of Capital

III. On the Magnitude of Adjustment Costs
A. Rich Countries $\left(\zeta_{\mathrm{R}}\right)$
B. Poor Relative to Rich Countries $(\lambda)$

IV Adjustment Costs and the Measurement of the Marginal Product of Capital across Countries

V. Accounting for the MPK Differential:

Adjustment Costs, Relative Prices, and Financial Frictions

VI. Summary
Appendix
References

Tables

Figure 


\section{The Marginal Product of Capital:}

\section{A Persistent International Puzzle}

\section{Introduction}

"Why Doesn't Capital Flow from Rich to Poor Countries?" This provocative question posed by Lucas (1990) initiated a line of research focusing on the substantial differences in the marginal product of capital (MPK) among countries. Large and sustained differences are sharply at odds with capital's pursuit of profitable investment opportunities and diminishing returns in production that are at the core of the neoclassical framework. Financial market frictions, relative factor prices, human capital, and total factor productivity, among other factors, have been advanced as explanations for international differences in MPKs, though no consensus has emerged. ${ }^{1}$ The outcome of this debate has important implications for development economics in general and foreign aid policies in particular.

In an important contribution, Caselli and Feyrer (CF, 2007) take the ground out from under this debate by carefully considering measurement issues. They conclude that, when properly measured, MPKs are largely equalized internationally. This radical conclusion follows from three innovations in measuring the MPK. First and most importantly, CF develop a method for measuring MPKs that is based on the neoclassical framework, requires few assumptions, and can be computed with available data. ${ }^{2}$ Their method confirms the standard result that the MPK in poor countries is much larger than in rich countries. The MPK differential - the ratio of the average MPKs for poor to rich countries - is 2.386. Second, CF refine the measurement of the capital share by "backing-out" the effects of land and natural resources that distort measures of the marginal product of reproducible capital. Based on newly available data from the World Bank, CF find that the MPK differential falls to 1.587. Third, the MPK measure is further refined by multiplication by the price of output relative to the price of investment. Combined with the modification of the capital share, the average MPKs for poor countries is now lower

\footnotetext{
${ }^{1}$ Banerjee and Duflo (2005) review some of the empirical evidence.

${ }^{2}$ The CF analysis requires data from the Penn World Table (Summers and Heston, 1991 and Heston, Summers, and Aten, 2004), Bernanke and Gurkaynak (2001), and the World Bank (2006).
} 
than that for rich countries; the MPK differential is 0.821 . Improved MPK measurement would seem to eliminate the need to address the Lucas question.

Despite the important advances in measurement by CF, the international MPK puzzle persists. We argue that there is a critical specification problem in the CF approach due to adjustment costs in accumulating capital and the resulting wedge between gross and net outputs. Implicit in the $\mathrm{CF}$ analysis is that gross and net outputs are equal. However, adjustment costs drive a wedge between these two definitions of output and affect the measurement of MPK. Adjustment costs are a central element in a multitude of input demand models and rightfully belong in the technology underlying the MPK calculations. As we demonstrate below, adjustment costs reverse the CF finding. Under plausible parametric assumptions, the MPK differential, even with the two CF corrections for the capital share and the relative output price, reverts to or exceeds its original value of 2.386 .

Our analysis of the impact of adjustment costs on the measurement of MPKs proceeds as follows. Section II presents the CF specification of the MPK based on an alternative derivation and then expands the model to recognize a role for adjustment costs. This general model depends on two parameters describing the adjustment cost technologies in poor and rich countries. Section III reviews evidence on the magnitude of adjustment costs in the United States and the extent to which adjustment costs are relatively higher in poor countries. The MPK differential depends positively on these two adjustment cost parameters interacting with the output/capital ratio, which is much higher in poor countries. Section IV simulates the model based on the two adjustment cost parameters and the CF data. For our preferred estimates of the adjustment cost parameters, the MPK differential is $100 \%$ to $200 \%$ higher than the estimate reported by CF. All of the above analysis focuses on the impact of adjustment costs on MPK measurement. Based on a dynamic optimizing model, Section V assesses how much of this difference can be accounted for by adjustment costs in comparison to two leading explanations, relative prices and financial frictions. Section VI summarizes our results.

\section{Measuring the Marginal Product of Capital}

CF present a direct method for measuring the MPK that can be implemented with available data. The required assumptions are that gross output $\left(\mathrm{Y}^{\mathrm{G}}\right)$ is determined by a 
neoclassical production function, G[.], depending on labor (L) and capital (K) inputs, G[L,K] is homogeneous of degree one in both inputs, and output and input markets are competitive. The following derivation differs from that of $\mathrm{CF}$, though we use the same assumptions and arrive at the same specification for the MPK. Using Euler's Theorem of Homogeneous Functions, we can write the production function as follows,

$$
\mathrm{Y}^{\mathrm{G}}=\mathrm{G}[\mathrm{L}, \mathrm{K}]=\mathrm{G}_{\mathrm{L}} \mathrm{L}+\mathrm{G}_{\mathrm{K}} \mathrm{K}
$$

where subscripts denote partial differentiation. Defining $M P K \equiv G_{K}$, equating $G_{L}$ to the wage rate $(\mathrm{w})$ per the assumption of a competitive labor market, and rearranging, we obtain the key equation (1) in $\mathrm{CF}$,

$$
\begin{aligned}
\operatorname{MPK} \equiv \mathrm{G}_{\mathrm{K}} & =\left(\mathrm{Y}^{\mathrm{G}}-\mathrm{w} \mathrm{L}\right) / \mathrm{K} \\
& =\left(\mathrm{Y}^{\mathrm{G}} / \mathrm{K}\right) *\left(1-\mathrm{w} \mathrm{L} / \mathrm{Y}^{\mathrm{G}}\right) \\
& =\left(\mathrm{Y}^{\mathrm{G}} / \mathrm{K}\right) * \alpha^{\mathrm{K}}
\end{aligned}
$$

where $\alpha^{\mathrm{K}}$ is the capital income share. Along with refinements for non-reproducible capital in the capital share and the relative price of output, equation (2) is the basis for the MPKs discussed in Section I and presented by CF in Tables II and III.

The provocative conclusion that follows from equation (2), however, is based on a misspecified technology. Since the work of Eisner and Strotz (1963) and Lucas (1967), the capital accumulation process has been constrained by adjustment costs. These costs represent lost output from disruptions to the existing production process, as new capital goods are "brokenin" and "fitted" and labor is diverted from production to "bolting-down" new capital. (Readers who have installed a new computer or added a room to their home have a keen appreciation of the importance of adjustment costs and the disruptions that drain resources.) These installation and "teething" costs are a standard element in modeling input demands (see the surveys by Nickell (1978), Maccini (1987), Chirinko (1993), Hamermesh and Pfann (1996), and Caballero (1999)) and play important roles for understanding the transition path and steady-state in growth 
models (Barro and Sala-i-Martin, 2004), the New Keynesian Phillips curve (Woodford, 2005), and productivity growth (Basu, Fernald, and Shapiro (2001) and Groth (2008)). Adjustment costs impact MPK measurement by driving a wedge between gross output $\left(\mathrm{Y}^{\mathrm{G}}\right)$ and net output $\left(\mathrm{Y}^{\mathrm{N}}\right)$.

This wedge is a fundamental impediment to measuring the MPK because, while gross output defines the MPK, it is unobservable. Published estimates of aggregate output are net of adjustment costs. ${ }^{3}$ (Returning to the example of adding a room to a home, the number of research papers written during the construction period would undoubtedly drop, and all that one's Department chair would observe is lower net output.) Internal adjustment costs are the focus of this paper and, being largely distant from market transactions, are nearly impossible to incorporate into national income measures of aggregate output. The United Nations' System of National Accounts (SNA, which underlie the Penn World Table estimates) excludes internal costs -- "[o]utput is the value of the goods and services which are produced by an establishment in the economy that become available for use outside that establishment..." (United Nations, 2004, p. 23). External adjustment costs may be reflected partly in the investment data entering $\mathrm{Y}^{\mathrm{N}}$ in those countries estimating aggregate output with expenditure data, as opposed to production or income data. ${ }^{4}$ However, "[m] ost often GDP is estimated by the production approach" (United Nations, 1999, p. 10, note 37).

The wedge between unobservable gross output and observable net output is bridged by specifying the adjustment cost technology. Following the literature, we assume that the adjustment cost function, $\mathrm{A}[\mathrm{I}, \mathrm{K}]$, depends on investment (I) and capital, is homogeneous of degree one, and is separable from gross output. These considerations lead to the following relation among net output, gross output, and adjustment costs,

\footnotetext{
${ }^{3}$ We thank Francesco Caselli for raising this issue.

${ }^{4}$ GDP can be estimated by one of three equivalent approaches - production, expenditure, or income. In the latter case, the labor required for installing capital will be reflected in higher compensation, thus seemingly raising GDP measured by income. However, labor diverted from production activities to installation activities will be reflected in lower salable output and lower profits, the latter cancelling the effects of the higher compensation. Thus, internal adjustment costs have the same impact on GDP regardless if the latter is measured by production, expenditure, or income.
} 


$$
\begin{aligned}
& \mathrm{Y}^{\mathrm{N}} \equiv \mathrm{G}[\mathrm{L}, \mathrm{K}]-\mathrm{A}[\mathrm{I}, \mathrm{K}]=\mathrm{G}_{\mathrm{K}} \mathrm{K}+\mathrm{G}_{\mathrm{L}} \mathrm{L}-\mathrm{A}_{\mathrm{I}} \mathrm{I}-\mathrm{A}_{\mathrm{K}} \mathrm{K}, \\
& \Rightarrow \\
& \mathrm{MPK} \equiv \mathrm{G}_{\mathrm{K}}-\mathrm{A}_{\mathrm{K}}=\left(\mathrm{Y}^{\mathrm{N}} / \mathrm{K}\right) *\left(\alpha^{\mathrm{K}}+\mathrm{A}_{\mathrm{I}} \mathrm{I} / \mathrm{Y}^{\mathrm{N}}\right) .
\end{aligned}
$$

To parameterize the adjustment cost function in a parsimonious manner, we adopt the familiar quadratic specification for adjustment costs (e.g., Barro and Sala-i-Martin (2004, Section 3.2), and Sargent (1987, Chapter XV)),

$$
\begin{aligned}
& A[\mathrm{I}, \mathrm{K}]=(\beta / 2) *\left(\mathrm{I}^{2} / \mathrm{K}\right), \\
& \Rightarrow \\
& \mathrm{A}_{\mathrm{I}} \mathrm{I}=2 * \mathrm{~A}[\mathrm{I}, \mathrm{K}] .
\end{aligned}
$$

Combining equations (3) and (4), we can estimate the MPK with the following equation,

$$
\operatorname{MPK}=\left(\mathrm{Y}^{\mathrm{N}} / \mathrm{K}\right) *\left(\alpha^{\mathrm{K}}+2 * \zeta\right)
$$

$$
\zeta \equiv \mathrm{A}[\mathrm{I}, \mathrm{K}] / \mathrm{Y}^{\mathrm{N}}
$$

where $\zeta$ measures adjustment costs relative to net output. The original CF model (equation (2)) is obtained as a special case of equation (5) when adjustment costs are absent $(\zeta=0)$. Equation (5) shows the appropriate way to "add back" adjustment costs to account for the wedge between gross and net outputs and obtain a more accurate measure of the MPK.

The derivation of the equation for estimating the MPK contained in this section differs from that in CF. While both derivations are based on the same set of neoclassical assumptions, CF derive equation (2) by assuming that the MPK computed from national income accounting data equals the financial rate of return (with corrections for depreciation and relative prices). However, the equality between the financial return and the MPK will not hold in the face of adjustment costs and the associated drain of real resources. The derivation presented here 
relying on Euler's Theorem of Homogeneous Functions clearly identifies the role of adjustment costs in raising the measured MPK.

Our expanded model can be computed with available data and values for the $\zeta$ parameter in poor and rich countries. Empirical evidence bearing on these two parameters will be examined in Section III, and simulations quantifying the sensitivity of the MPK differential to adjustment costs and other factors will be undertaken in Section IV. But, at this point, it is clear from equation (5) that the introduction of adjustment costs raises the measured MPK differential for two separate reasons. First, if the $\zeta$ 's are equal in poor and rich countries, then the relatively higher output/capital ratio in poor countries will raise the MPK differential. Introspection suggests, however, that $\zeta$ is greater in poor countries. This difference will be a second factor contributing to the relative increase in the measured MPK for poor countries when adjustment costs are taken into account.

\section{On the Magnitude of Adjustment Costs}

The relation between the MPKs for poor and rich countries depends on the output/capital ratio and capital income share, as in the CF study, and on two parameters describing adjustment cost technologies. The MPKs in poor and rich countries will be evaluated in Section IV. But first, we estimate the two adjustment cost parameters using equations (4) and (5) and existing empirical evidence.

\section{III.A. Rich Countries $\left(\zeta_{\mathrm{R}}\right)$}

The most extensive set of studies estimating adjustment cost parameters has been based on US data, and we use these results to estimate the ratio of adjustment costs to net output for the rich countries $\left(\zeta_{\mathrm{R}}\right)$. The cross-model comparisons are enhanced by an additional common element -- all models (save the last one) discussed in this subsection and listed in Table I can be derived from one general adjustment cost model containing an unobservable shadow price of capital. ${ }^{5}$ The models differ only by the way in which applied researchers relate the unobservable shadow price to observable variables.

\footnotetext{
${ }^{5}$ See Chirinko (1993, Section III and V.B.) for further discussion of adjustment costs models.
} 
TABLE I

Estimates Of Adjustment Cost Parameters

\begin{tabular}{|l|c|c|l|}
\hline Study & $\beta_{\mathrm{R}}$ & $\zeta_{\mathrm{R}}$ & Characteristics \\
\hline $\begin{array}{l}\text { Hayashi } \\
(1982)\end{array}$ & 23.641 & 0.162 & $\begin{array}{l}\text { Stock Market Q Equation } \\
\text { Aggregate Data }\end{array}$ \\
\hline $\begin{array}{l}\text { Gilchrist and Himmelberg } \\
(1995)\end{array}$ & 20.000 & 0.137 & $\begin{array}{l}\text { Stock Market Q Equation } \\
\text { Firm Panel Data }\end{array}$ \\
\hline $\begin{array}{l}\text { Barnett and Sakellaris } \\
(1998)\end{array}$ & 51.282 & 0.352 & $\begin{array}{l}\text { Stock Market Q Equation } \\
\text { Firm Panel Data }\end{array}$ \\
\hline $\begin{array}{l}\text { Abel and Blanchard } \\
(1986)\end{array}$ & 76.923 & 0.528 & $\begin{array}{l}\text { Linear Projection Q Equation } \\
\text { Aggregate Data }\end{array}$ \\
\hline $\begin{array}{l}\text { Gilchrist and Himmelberg } \\
(1995)\end{array}$ & 5.464 & 0.038 & $\begin{array}{l}\text { Linear Projection Q Equation } \\
\text { Firm Panel Data }\end{array}$ \\
\hline $\begin{array}{l}\text { Shapiro } \\
(1986)\end{array}$ & 5.443 & 0.037 & $\begin{array}{l}\text { Euler Equation } \\
\text { Aggregate Data }\end{array}$ \\
\hline $\begin{array}{l}\text { Chirinko (1995), Capital } \\
\text { Adjustment Costs }\end{array}$ & 4.481 & 0.031 & $\begin{array}{l}\text { Euler And Stock Market Q Equations } \\
\text { Aggregate Data }\end{array}$ \\
\hline $\begin{array}{l}\text { Chirinko (1995), Capital + } \\
\text { Employment Adjustment Costs }\end{array}$ & ---- & 0.045 & $\begin{array}{l}\text { Euler And Stock Market Q Equations } \\
\text { Aggregate Data }\end{array}$ \\
\hline $\begin{array}{l}\text { Cooper and Haltiwanger } \\
\text { (2006) }\end{array}$ & ---- & 0.053 & $\begin{array}{l}\text { Indirect Inference } \\
\text { Plant Panel Data }\end{array}$ \\
\hline $\begin{array}{l}\text { Cooper and Haltiwanger } \\
\text { (2006) }\end{array}$ & ---- & 0.069 & $\begin{array}{l}\text { Indirect Inference } \\
\text { Plant Panel Data } \\
\text { Controlling for Endogeneity }\end{array}$ \\
\hline
\end{tabular}

Notes to Table I: See the Appendix for details concerning the calculations underlying the estimates of the parameters. The adjustment cost function parameter $\left(\beta_{R}\right)$ enters equation (4). The adjustment costs/net output ratio $\left(\zeta_{R}\right)$ is defined in equation $(5)$ and discussed in subsection III.A. 
The first three studies are based on the Brainard-Tobin Q model that relates investment spending to stock market Q. With aggregate data, Hayashi (1982) reports an estimate of $\beta_{\mathrm{R}}=23.641$, which implies $\zeta_{\mathrm{R}}=0.162$. (A detailed discussion of the econometric studies reviewed in this subsection and their implications for $\beta_{R}$ and $\zeta_{R}$ is presented in the Appendix.) With firm panel data, Gilchrist and Himmelberg $\left(1995 ; \zeta_{\mathrm{R}}=0.137\right)$ obtain similar results, and Barnett and Sakellaris $\left(1998 ; \zeta_{\mathrm{R}}=0.352\right)$ report more substantial adjustment costs. All of these estimates based on stock market Q imply quite large adjustment costs.

Stock market Q studies have been criticized for estimating parameters implying unreasonably long adjustment periods for capital accumulation in response to a shock and hence unreasonably large adjustment costs. This pattern has been linked to excess volatility in stock market Q, perhaps due to bubbles, noise, or other nonfundamental influences on stock prices. In response to this concern, researchers have pursued two alternative estimation strategies. One set of studies replaces stock market Q with linear projection Q, defined by a linear projection of variables known in a given time period and unlikely to be affected by stock market misvaluations. The effects on adjustment cost parameters of substituting linear projection Q for stock market Q are mixed. With aggregate data, Abel and Blanchard (1986) find that adjustment costs continue to be sizeable: $\zeta_{\mathrm{R}}=0.528$. However, with firm panel data, Gilchrist and Himmelberg (1995) report much lower adjustment costs: $\zeta_{\mathrm{R}}=0.038$.

A second set of studies avoids possible biases due to volatility in stock market Q by estimating the Euler equation characterizing optimal behavior. With aggregate data, Shapiro (1986) estimates a system of equations that includes Euler equations for capital, production workers, nonproduction workers, and hours, as well as the wage bill. He reports estimates of $\beta_{\mathrm{R}}=5.443$ and $\zeta_{\mathrm{R}}=0.037$ that are remarkably close to Gilchrist and Himmelberg's estimates with linear projection Q.

As noted above, the econometric equations considered so far differ only by the way in which the unobservable shadow price for capital is related to observable variables. Chirinko (1995) combines the Q and Euler solutions to the unobservable shadow price problem and, with aggregate data, estimates an equation system that includes a stock market $Q$ equation and the Euler equation for capital, as well as the Euler equation for employees, a pricing equation setting marginal revenue equal to marginal cost, and an hours equation based on an inverted production 
function. His framework permits two estimates of $\zeta_{\mathrm{R}}$. The first approach directly estimates $\beta_{\mathrm{R}}=4.481$, which implies $\zeta_{\mathrm{R}}=0.031$.

The second approach broadens the analysis to include employment adjustment costs and their impact on the measurement of the MPK. While employment adjustment costs do not directly affect the marginal return to capital, they -- like capital adjustment costs -- affect MPK measurement based on Euler's Theorem of Homogeneous Functions. Reevaluating equations (3) to (5) with homogeneous adjustment cost functions for capital $(\mathrm{A}[\mathrm{I}, \mathrm{K}])$ and labor $(\mathrm{H}[\ell, \mathrm{L}]$, where $\ell$ is the change in number of employees), the specification of the MPK is the same as in equation (5) with $\zeta$ replaced by $\zeta^{\prime}$,

$$
\begin{aligned}
\zeta^{\prime} \equiv(\zeta+\phi) / 2, \\
\phi \equiv(\mathrm{A}[\mathrm{I}, \mathrm{K}]+\mathrm{H}[\ell, \mathrm{L}]) / \mathrm{Y}^{\mathrm{N}},
\end{aligned}
$$

where $\zeta^{\prime}=\zeta$ when $H[]=$.0 . The second approach in Chirinko (1995) generates a direct estimate of $\phi=0.058$, which implies $\zeta_{\mathrm{R}}^{\prime}=0.045$. $^{6}$

The above estimates are based on the convex adjustment cost model. Recent work has emphasized two additional adjustment costs - nonconvexities (due to fixed adjustment costs) and costly reversibilities (due to a gap between purchase and resell prices of capital goods). These additional costs disrupt the homogeneity and differentiability properties, respectively, of the production function, and hence estimates from these models can not be analyzed in the current framework relying on Euler's Theorem. Nonetheless, an estimate of average adjustment costs due to nonconvexities, costly reversibilities, and convexities relative to net output, $\zeta$ ", can serve as a useful robustness check. With plant panel data, the estimates of Cooper and Haltiwanger (2006) imply that $\zeta{ }^{\prime \prime}=0.053$. When they control for endogeneity, the estimate of $\zeta$ " rises to 0.069 .

In sum, the latter four studies seem to deliver the most plausible estimates and suggest that the adjustment costs/net output ratio for the United States varies between $3.0 \%$ and $6.0 \%$. We favor estimates toward the upper end of this range because, as the data in Section III.B will

\footnotetext{
${ }^{6}$ Based on these estimates, employment adjustment costs are $87 \%$ as large as capital adjustment costs.
} 
document, adjustment costs tend to decrease with per capita GDP. Since the United States is the richest of the rich countries in this dataset, the US estimate is likely a downwardly biased estimate for rich countries as a group. We conclude that a reasonably conservative estimate for the adjustment costs/net output ratio for rich countries, $\zeta_{\mathrm{R}}$, is $4.0 \%$ to $5.0 \%$.

\section{III.B. Poor Relative to Rich Countries $(\lambda)$}

The simulations also require a measure of the adjustment costs/net output ratio for poor countries. Estimating this parameter from econometric studies of the sort examined in Section III.A is not feasible because few, if any, such studies exist for the poor countries. Instead, we rely on proxies to estimate the relative adjustment costs between poor and rich countries,

$$
\lambda \equiv \zeta_{\mathrm{P}} / \zeta_{\mathrm{R}}
$$

where $\zeta_{\mathrm{P}}$ is the ratio of adjustment costs to net output for poor countries (cf., equation (5)). Four proxies that quantify internal adjustment costs are drawn from two studies that have examined entrepreneurial activity across countries. We are thus assuming that these proxies adequately capture the frictions and impediments to entrepreneurial activity and are proportional to the true adjustment costs facing all firms when accumulating capital.

The first proxy is taken from the study of the regulation of entrepreneurial activity by Djankov, La Porta, Lopez-de-Silanes, and Shleifer (2002). They compile several measures of the costs associated with obtaining legal status to operate a firm (stated as a fraction of per capita GDP). The direct out-of-pocket costs include all "identifiable official expenses (fees, costs of procedures and forms, photocopies, fiscal stamps, legal and notary charges, etc.) as well as the monetized value of the entrepreneur's time" (Djankov, et. al., p. 16.). These "Cost + Time" data are presented in the first row of Panel A in Table II. The ratio of the mean values for poor to rich countries presented in column 7 is 2.735 .

The remaining three proxies are obtained from the World Bank project Doing Business. The "Dealing with Licenses" proxy "tracks the procedures, time, and costs to build a warehouse, including obtaining necessary licenses and permits, completing required notifications and inspections, and obtaining utility connections;" the data are presented in terms of cost as a percentage of income per capita. The "Registering Property" proxy "examines the steps, time, and cost involved in registering property, assuming a standardized case of an entrepreneur who 
TABLE II

Source Data For Poor And Rich Countries And The United States

\begin{tabular}{|c|c|c|c|c|c|c|c|c|}
\hline & \multicolumn{3}{|c|}{ POOR COUNTRIES } & \multicolumn{3}{|c|}{ RICH COUNTRIES } & \multirow{2}{*}{$\begin{array}{l}\text { Cols. } \\
(1) /(4)\end{array}$} & \multirow{2}{*}{\begin{tabular}{|l|} 
USA \\
Mean
\end{tabular}} \\
\hline & Mean & $\begin{array}{l}\text { Std. } \\
\text { Dev. }\end{array}$ & $\mathbf{N}$ & Mean & $\begin{array}{l}\text { Std. } \\
\text { Dev. }\end{array}$ & $\mathbf{N}$ & & \\
\hline & (1) & (2) & (3) & (4) & (5) & (6) & (7) & (8) \\
\hline \multicolumn{9}{|l|}{$\begin{array}{l}\text { A. Adjustment } \\
\text { Costs Proxies }\end{array}$} \\
\hline $\begin{array}{l}\text { DLLS: } \\
\text { Cost + Time }\end{array}$ & 0.651 & 0.627 & 19 & 0.238 & 0.189 & 23 & 2.735 & 0.017 \\
\hline & & & & & & & & \\
\hline \multicolumn{9}{|l|}{$\begin{array}{l}\text { World Bank } \\
\text { Doing Business }\end{array}$} \\
\hline $\begin{array}{l}\text { Dealing With } \\
\text { Licenses }\end{array}$ & 220.242 & 184.316 & 24 & 72.352 & 44.199 & 23 & 3.044 & 16.000 \\
\hline $\begin{array}{l}\text { Registering } \\
\text { Property }\end{array}$ & 7.210 & 5.754 & 29 & 4.448 & 3.283 & 23 & 1.621 & 0.500 \\
\hline $\begin{array}{r}\text { Starting A } \\
\text { Business } \\
\end{array}$ & 49.938 & 61.162 & 29 & 5.187 & 6.497 & 23 & 9.628 & 0.700 \\
\hline & & & & & & & & \\
\hline$\lambda$ & & & & & & & 4.257 & \\
\hline \multicolumn{9}{|l|}{$\begin{array}{l}\text { B. Caselli/Feyrer } \\
\text { Data }\end{array}$} \\
\hline$\left(\mathrm{Y}^{\mathrm{N}} / \mathrm{K}\right) * \alpha_{\mathrm{K}} *\left(\mathrm{P}_{\mathrm{Y}} / \mathrm{P}_{\mathrm{K}}\right)$ & 0.069 & 0.037 & 29 & 0.084 & 0.019 & 23 & & 0.094 \\
\hline$\left(\mathrm{Y}^{\mathrm{N}} / \mathrm{K}\right)$ & 0.738 & 0.276 & 29 & 0.371 & 0.062 & 23 & & 0.456 \\
\hline$(\mathrm{I} / \mathrm{K})$ & 0.070 & 0.027 & 29 & 0.072 & 0.021 & 23 & & 0.079 \\
\hline$\left(\mathrm{I} / \mathrm{Y}^{\mathrm{N}}\right)$ & 0.107 & 0.058 & 29 & 0.197 & 0.063 & 23 & & 0.174 \\
\hline
\end{tabular}

Notes to Table II: The definitions of poor and rich countries are the same as used by CF: poor countries are those with GDP per worker less than or equal to 26,113 (the value for Malaysia) in purchasing power parity for 1996; rich countries are those with GDP per worker greater than or equal to 30,086 (the value for Portugal) in purchasing power parity for 1996. The coverage of the four proxies - "Cost + Time," "Dealing With Licenses," "Registering Property," and "Starting A Business" - are discussed in Section III.B. The "Cost + Time" proxy is obtained from Djankov, La Porta, Lopez-de-Silanes, and Shleifer (2002, Table III). The remaining three proxies are from the World Bank's Doing Business webpage (http://www.doingbusiness.org/). The $\lambda$ parameter is the mean value of the entries in column 7 and is defined in equation (7). The data in panel B are presented in CF (Table II); we use the more precise data available on Francesco Caselli's webpage. Hong Kong is excluded for lack of data. $\mathrm{N}$ is the number of countries in the poor or rich categories. 
wants to purchase land and a building in the largest business city - already registered and free of title dispute;" the data are presented in terms of cost as a percentage of property value. The third proxy concerns "Starting A Business" and "identifies the bureaucratic and legal hurdles an entrepreneur must overcome to incorporate and register a new firm;" the data are presented in terms of cost as a percentage of GNI per capita. The data are displayed in the second to fourth rows of Panel A in Table II. The ratios of the mean values for poor to rich countries presented in column 7 are $3.044,1.621$, and 9.628, respectively.

The proxies clearly indicate that adjustment costs are relatively higher in poor countries. The mean value of the four ratios is 4.257. Since entrepreneurs are likely to face greater costs than established firms, this figure may be an upwardly biased measure for the economy as a whole. Alternatively, some of the impediments facing domestic entrepreneurs may be less than those confronting foreign firms importing capital from abroad, an important mechanism for equating MPKs internationally. We conclude that a reasonably conservative estimate of the ratio between poor and rich countries of the adjustment costs/net output ratio, $\lambda$, is 2.00 to 3.00 .

\section{Adjustment Costs and the Measurement Of the Marginal Product of Capital across Countries}

The key relation in which we are interested is the MPK differential - the ratio of the average MPKs for poor to rich countries. The MPK differential is defined by a parameter, $\Phi$,

$$
\Phi \equiv \frac{\operatorname{MEAN}_{\mathrm{c} \in \mathrm{C}_{\mathrm{P}}}\left\{\mathrm{MPK}_{\mathrm{c}}\right\}}{\operatorname{MEAN}_{\mathrm{c} \in \mathrm{C}_{\mathrm{R}}}\left\{\mathrm{MPK}_{\mathrm{c}}\right\}}
$$

where $C_{P}$ and $C_{R}$ represent the set of poor and rich countries, respectively, and MEAN \{.\} is an operator computing the mean value over all c countries in a given set. Using equation (5) to substitute for the MPKs, we measure $\Phi$ as follows, 


$$
\begin{gathered}
\Phi\left[\zeta_{\mathrm{R}}, \lambda\right]=\frac{\mathrm{MPK}_{\mathrm{P}}^{\mathrm{CF}}+\mathrm{ADJU}_{\mathrm{P}}}{\mathrm{MPK}_{\mathrm{R}}^{\mathrm{CF}}+\mathrm{ADJU}_{\mathrm{R}}}, \\
\mathrm{MPK}_{\mathrm{x}}^{\mathrm{CF}} \equiv \operatorname{MEAN}_{\mathrm{c} \in \mathrm{C}_{\mathrm{x}}}\left\{\left(\mathrm{Y}^{\mathrm{N}} / \mathrm{K}\right)_{\mathrm{c}} * \alpha_{\mathrm{c}}^{\mathrm{K}}\right\}, \quad \mathrm{x}=\{\mathrm{P}, \mathrm{R}\} \\
\mathrm{ADJU}_{\mathrm{P}} \equiv 2 * \lambda * \zeta_{\mathrm{R}} * \mathrm{MEAN}_{\mathrm{c} \in \mathrm{C}_{\mathrm{P}}}\left\{\left(\mathrm{Y}^{\mathrm{N}} / \mathrm{K}\right)_{\mathrm{c}}\right\}, \\
\mathrm{ADJU}_{\mathrm{R}} \equiv 2 * \zeta_{\mathrm{R}} * \operatorname{MEAN}_{\mathrm{c} \in \mathrm{C}_{\mathrm{P}}}\left\{\left(\mathrm{Y}^{\mathrm{N}} / \mathrm{K}\right)_{\mathrm{c}}\right\}
\end{gathered}
$$

The MPK differential depends on averages of the output/capital ratio and capital share, both of which are determined by the available data, and the adjustment cost parameters, $\zeta_{\mathrm{R}}$ and $\zeta_{\mathrm{P}}=\lambda * \zeta_{\mathrm{R}}$. When adjustment costs are absent, equation (9) reduces to the ratio of average MPKs computed by $\mathrm{CF}$, and $\Phi[0,0]=0.821$. More generally, $\Phi\left[\zeta_{\mathrm{R}}, \lambda\right]$ depends primarily on the two adjustment cost parameters interacting with the output/capital ratio. In evaluating the impact of adjustment costs on relative MPKs, it proves convenient to examine MPK differentials relative to the original CF estimate, and we define the normalized MPK differential as follows,

$$
\Theta\left[\zeta_{\mathrm{R}}, \lambda\right] \equiv \frac{\Phi\left[\zeta_{\mathrm{R}}, \lambda\right]}{\Phi[0,0]}-1.0 .
$$

Table III simulates $\Theta\left[\zeta_{R}, \lambda\right]$ based on alternative values of the adjustment cost parameters ranging from $\zeta_{\mathrm{R}}=\{0.00,0.10)$ in increments of 0.01 and $\lambda=\{1.00,1.10,1.25$, $1.50,1.75,2.00,3.00,5.00\}$. The first row contains zeroes because of the normalization relative to the CF estimate (per equation (10)). The estimates in column 1 are based on equal adjustment cost parameters between poor and rich countries and range from $11.5 \%$ to $66.7 \%$. For our preferred values of $\zeta_{R}=\{0.04,0.05)$, the differences are $37.1 \%$ and $43.6 \%$, respectively.

The remaining entries in Table III recognize that adjustment costs in poor countries are larger than in rich countries by allowing $\lambda$ to exceed unity. The interactions are complex, 
TABLE III

The Normalized MPK Differential: $\Theta$

\begin{tabular}{|c|c|c|c|c|c|c|c|c|}
\hline & \multicolumn{7}{|c|}{$\boldsymbol{\lambda}$} \\
\hline$\zeta_{\mathrm{R}}$ & $\mathbf{1 . 0 0}$ & $\mathbf{1 . 2 5}$ & $\mathbf{1 . 5 0}$ & $\mathbf{1 . 7 5}$ & $\mathbf{2 . 0 0}$ & $\mathbf{3 . 0 0}$ & $\mathbf{4 . 0 0}$ & $\mathbf{5 . 0 0}$ \\
\hline & $(1)$ & $(2)$ & $(3)$ & $(4)$ & $(5)$ & $(6)$ & $(7)$ & $(8)$ \\
\hline 0.00 & 0.000 & 0.000 & 0.000 & 0.000 & 0.000 & 0.000 & 0.000 & 0.000 \\
\hline 0.01 & 0.115 & 0.165 & 0.214 & 0.263 & 0.312 & 0.508 & 0.705 & 0.902 \\
\hline 0.02 & 0.213 & 0.304 & 0.395 & 0.486 & 0.577 & 0.941 & 1.304 & 1.668 \\
\hline 0.03 & 0.298 & 0.425 & 0.551 & 0.678 & 0.805 & 1.312 & 1.820 & 2.327 \\
\hline 0.04 & 0.371 & 0.529 & 0.687 & 0.845 & $\mathbf{1 . 0 0 3}$ & $\mathbf{1 . 6 3 6}$ & 2.268 & 2.900 \\
\hline 0.05 & 0.436 & 0.621 & 0.806 & 0.992 & $\mathbf{1 . 1 7 7}$ & $\mathbf{1 . 9 1 9}$ & 2.661 & 3.403 \\
\hline 0.06 & 0.492 & 0.702 & 0.912 & 1.122 & 1.331 & 2.170 & 3.009 & 3.848 \\
\hline 0.07 & 0.543 & 0.775 & 1.006 & 1.237 & 1.468 & 2.394 & 3.319 & 4.244 \\
\hline 0.08 & 0.589 & 0.839 & 1.090 & 1.341 & 1.591 & 2.594 & 3.597 & 4.600 \\
\hline 0.09 & 0.630 & 0.898 & 1.166 & 1.434 & 1.702 & 2.775 & 3.847 & 4.920 \\
\hline 0.10 & 0.667 & 0.951 & 1.235 & 1.519 & 1.803 & 2.938 & 4.074 & 5.210 \\
\hline
\end{tabular}

Notes to Table III: The Normalized MPK Differential $(\Theta)$ is defined in equation (10). The adjustment costs/net output ratio $\left(\zeta_{\mathrm{R}}\right)$ is defined in equation (5) and discussed in subsection III.A. Relative adjustment costs between poor and rich countries $(\lambda)$ is defined in equation (7) and discussed in Section III.B. All entries are stated as percentage changes relative to the ratio of the MPKs from poor and rich countries reported by Caselli-Feyrer of 0.821. Entries in boldface are based on our preferred parameter values of $\zeta_{R}=\{0.04,0.05\}$ and $\lambda=\{2.00,3.00\}$.

though $\Theta\left[\zeta_{R}, \lambda\right]$ uniformly increases in $\zeta_{R}$ and $\lambda$. To place some structure on these voluminous results, the Figure plots $\Theta\left[\zeta_{R}, \lambda\right]$ against $\zeta_{R}$ for four values of $\lambda=\{1.0,1.5,2.0,3.0\}$. The plots clearly document the sensitivity of the MPK differential to the introduction of adjustment costs. Our preferred range of estimates are $\zeta_{R}=\{0.04,0.05\}$ and $\lambda=\{2.00,3.00\}$, and the normalized MPK differentials range from 1.00 to nearly 2.00. The initial estimate of the normalized MPK differential by CF without their corrections to the capital share and inclusion of the relative price of output is $1.906(=(2.386 / 0.821)-1.0)$, within the range of estimates implied by our model with the two CF corrections and the preferred adjustment cost parameters. Table III and the Figure document that adjustment costs have a notable impact on the measurement of the MPK differential. 
FIGURE

Normalized MPK Differential $(\Theta)$ vs. $\zeta_{R}$ For Various $\lambda$ 's

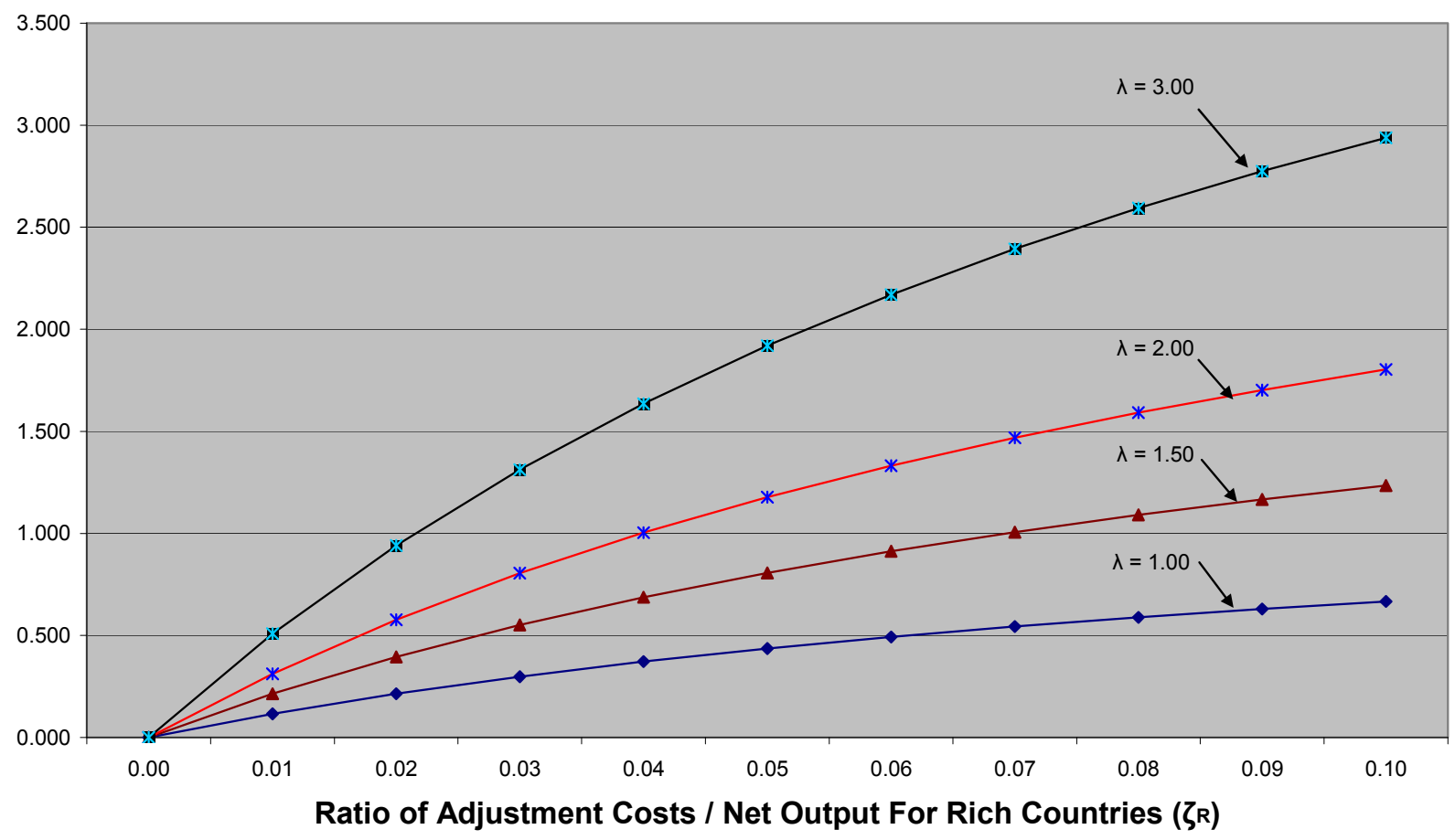

V. Accounting for the MPK Differential:

Adjustment Costs, Relative Prices, and Financial Frictions

All of the above analysis has focused on the impact of adjustment costs on MPK measurement. As discussed in Section IV, the impact is substantial, and the MPKs in poor countries are much larger than those in rich countries. This section offers a quantitative assessment of how much of this differential can be explained by adjustment costs in comparison to two leading explanations, relative prices and financial frictions.

We begin with the standard first-order condition for investment that emerges from a dynamic optimization problem containing adjustment costs, ${ }^{7}$

\footnotetext{
${ }^{7}$ See Chirinko (1993, Section III.A) for further discussion of this first-order condition and the associated maximization problem. CF use a similar relation without adjustment costs; see their equation (5).
} 


$$
\Psi=\mathrm{P}^{\mathrm{IY}} *\left(1.0+\mathrm{A}_{\mathrm{I}}[\cdot]\right)
$$

Equation (11) is the dynamic equivalent of the simple decision rule for the optimal capital stock equating the marginal benefit $-\Psi$, the sum of current and future MPKs discounted by the financial cost of capital $(\rho)$ and decremented by the rate of capital depreciation $(\delta)$ - to the marginal costs of acquiring capital. The marginal costs depend on the purchase cost $-\mathrm{P}^{\mathrm{IY}}$, the price of investment relative to the price of output - and the marginal adjustment cost $-A_{I}[$.$] .$ Along a balanced growth path, all of these variables are constant, and the discounted sum of MPKs in equation (11) can be written as follows,

$$
\begin{aligned}
& \frac{\mathrm{MPK}}{(\rho+\delta)}=\mathrm{P}^{\mathrm{IY}} *\left(1.0+\mathrm{A}_{\mathrm{I}}[\cdot]\right) \\
& \quad \Rightarrow \\
& \mathrm{MPK}=\mathrm{P}^{\mathrm{IY}} *\left(1.0+\mathrm{A}_{\mathrm{I}}[\cdot]\right) *(\rho+\delta) .
\end{aligned}
$$

We assume that the MPKs for poor and rich countries can be characterized by equation (12), and hence their ratio generates a second, independent relation for the MPK differential.

The ability of this model based on the dynamic decision rule to explain the MPK differential measured by equation (9) is evaluated with the following statistic,

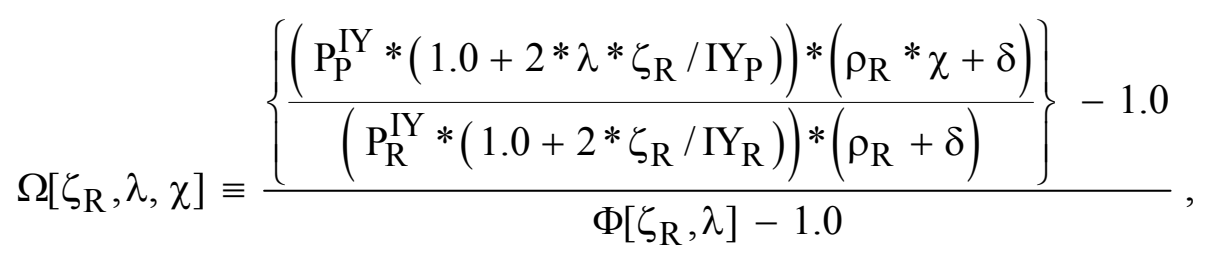

where subscripts have been added to denote the poor and rich countries, the marginal adjustment cost functions have been restated (per equations (4) and (5) and with $\mathrm{IY}_{\mathrm{x}}$ equal to the investment/output ratio), and the financial cost of capital for poor countries has been replaced by the product of the financial cost of capital for rich countries and a parameter, $\chi \geq 1$, representing 
financial market frictions that may affect poor countries. Some of the leading explanations of the MPK differential -- relative price differences (Hsieh and Klenow, 2007) and financial market frictions (Lucas, 1990; CF, 2007) -- can be understood in terms of Equation (13). When equation (13) equals 1.0, all of the MPK differential (in the denominator) is explained by the decision rule governing optimal investment (in the numerator).

The extent to which adjustment costs, relative prices, and financial frictions account for the MPK differential is evaluated as follows. We begin by assuming specific values for $\zeta_{\mathrm{R}}$ and $\lambda$. To assess the extent to which adjustment costs alone account for the MPK differential, we "turn-off" the effects of the relative price and financial frictions by setting $\mathrm{P}_{\mathrm{P}}^{\mathrm{IY}}=\mathrm{P}_{\mathrm{R}}^{\mathrm{IY}}=1.0$ and $\chi=1$, respectively, and compute the following ratio,

$$
\Omega_{\mathrm{A}_{\mathrm{I}}}\left[\zeta_{\mathrm{R}}, \lambda\right] \equiv \frac{\left\{\frac{\left(1.0+2 * \lambda * \zeta_{\mathrm{R}} / \mathrm{IY}_{\mathrm{P}}\right)}{\left(1.0+2 * \zeta_{\mathrm{R}} / \mathrm{IY}_{\mathrm{R}}\right)}\right\}-1.0}{\Phi\left[\zeta_{\mathrm{R}}, \lambda\right]-1.0}
$$

In a similar manner, we evaluate the explanatory power of relative prices by "turning-off" the effects of adjustment costs and financial frictions and computing the following ratio,

$$
\Omega_{\mathrm{P}^{I Y}}\left[\zeta_{\mathrm{R}}, \lambda\right] \equiv \frac{\left\{\frac{\mathrm{P}_{\mathrm{P}}^{\mathrm{IY}}}{\mathrm{P}_{\mathrm{R}}^{I \mathrm{Y}}}\right\}-1.0}{\Phi\left[\zeta_{\mathrm{R}}, \lambda\right]-1.0} .
$$

Lastly, the impact of financial frictions is assessed by "turning-off" the influences of relative prices and adjustment costs in the following equation,

$$
\Omega_{\chi}\left[\zeta_{\mathrm{R}}, \lambda, \chi\right] \equiv \frac{\left\{\frac{\left(\rho_{\mathrm{R}} * \chi+\delta\right)}{\left(\rho_{\mathrm{R}}+\delta\right)}\right\}-1.0}{\Phi\left[\zeta_{\mathrm{R}}, \lambda\right]-1.0} .
$$


To evaluate equation (14c), we need to make three additional assumptions: $\rho_{\mathrm{R}}=0.07$ (based on the long-run return to equity in the United States), $\delta=0.06(\mathrm{CF}, \mathrm{p} .544)$, and a range of values for $\chi=\{1.25,1.50,1.75,2.00\}$.

Table IV presents values for the $\Omega[$.$] statistics under the restrictions discussed above and$ with our preferred range of adjustment cost parameters, $\zeta_{R}=\{0.04,0.05\}$ and $\lambda=\{2.00,3.00\}$. As indicated in the first row, adjustment costs are able to account for the MPK differential. ${ }^{8}$ For example, the entry in column 1 of 1.200 indicates that $120.0 \%$ of the MPK differential defined in equation (9) is accounted for by the ratio of first-order conditions from a dynamic optimization model (equation (12)). The amount explained remains nearly constant as the importance of adjustment costs are increased in the remaining three columns.

Relative prices also explain the MPK differential. When adjustment costs are small, differences in the relative price of investment goods between poor and rich countries explain $134.3 \%$ of the MPK differential (as shown in the second row). However, as adjustment costs become relatively more important in poor countries, the ratio drops to $74.4 \%$ and $62.0 \%$.

Financial frictions are evaluated with the entries in the remaining four rows. This hypothesis was rejected by Lucas (1990) as an explanation of the MPK differential. His conclusion is confirmed here. Except when adjustment costs are low and financial frictions are very large (doubling the financial cost of capital in poor relative to rich countries), the entries in the third to sixth rows indicate that financial frictions can not adequately account for the MPK differential.

In sum, these computations suggest that, among the three factors considered here, adjustment costs provide the leading explanation of the MPK differential between poor and rich countries. It should be noted that the analysis in this section is based on convex adjustment costs. Non-convex and asymmetric adjustment costs provide an additional channel for explaining the MPK differential. As noted in Section III.A, these adjustment costs might arise if

\footnotetext{
${ }^{8}$ While adjustment costs are included in both the numerator and denominator of equation (14a), they enter for two independent reasons -- the denominator as a result of Euler's Theorem of Homogeneous Functions and the numerator from the first-order condition for dynamic profit maximization. There is no necessary reason why the latter should account for the former. Indeed, adjustment cost parameters are not the fundamental driving force underlying the results in row 1. If the investment/output ratios in the two sets of countries are equalized to their weighed-average of 0.147 , the entries in the first row of Table IV are approximately halved, and the corresponding entries become $0.546,0.513,0.605$, and 0.579 .
} 
TABLE IV

Accounting For the MPK Differential

\begin{tabular}{|c|c|c|c|c|}
\hline & \multicolumn{4}{|c|}{ Adjustment Cost Parameters } \\
\hline Statistic & $\begin{array}{c}\zeta_{R}=0.04 \\
\lambda=2.00\end{array}$ & $\begin{array}{c}\zeta_{\mathrm{R}}=\mathbf{0 . 0 5} \\
\lambda=\mathbf{2 . 0 0}\end{array}$ & $\begin{array}{c}\zeta_{R}=0.04 \\
\lambda=3.00\end{array}$ & $\begin{array}{c}\zeta_{R}=0.05 \\
\lambda=3.00\end{array}$ \\
\hline & $(1)$ & $(3)$ & $(2)$ & $(4)$ \\
\hline $\begin{array}{l}\text { Adjustment Costs } \\
\Omega_{\mathrm{A}_{\mathrm{I}}}\left[\zeta_{\mathrm{R}}, \lambda\right]\end{array}$ & 1.200 & 1.145 & 1.121 & 1.089 \\
\hline $\begin{array}{l}\text { Relative Prices } \\
\Omega_{\mathrm{P}^{\mathrm{IY}}}\left[\zeta_{\mathrm{R}}, \lambda\right]\end{array}$ & 1.343 & 1.099 & 0.744 & 0.620 \\
\hline $\begin{array}{l}\text { Financial Frictions } \\
\Omega_{\chi}\left[\zeta_{\mathrm{R}}, \lambda, \chi\right]\end{array}$ & & & & \\
\hline$\chi=1.25$ & 0.208 & 0.171 & 0.116 & 0.096 \\
\hline$\chi=1.50$ & 0.417 & 0.341 & 0.231 & 0.193 \\
\hline$\chi=1.75$ & 0.625 & 0.512 & 0.347 & 0.289 \\
\hline$\chi=2.00$ & 0.834 & 0.683 & 0.462 & 0.385 \\
\hline
\end{tabular}

Notes to Table IV: The entries are the proportion of the MPK differential (stated as a percentage change from the MPK for rich countries) accounted for the by ratio of first-order conditions from a dynamic decision rule describing capital accumulation for poor and rich countries (stated as a percentage change from the MPK for rich countries). The entries are evaluated for various restrictions that isolate the impact of adjustment $\operatorname{costs}\left(\Omega_{\mathrm{A}_{\mathrm{I}}}[].\right)$, relative prices $\left(\Omega_{\mathrm{P}^{\mathrm{IY}}}[].\right)$, and financial frictions $\left(\Omega_{\chi}[].\right)$ and various combinations of adjustment cost and financial friction parameters. The $\Omega_{\mathrm{A}_{\mathrm{I}}}[],. \Omega_{\mathrm{P}^{\mathrm{IY}}}\left[\right.$.] , and $\Omega_{\chi}$ [.] statistics are defined in equations (13) and (14). The adjustment costs/net output ratio $\left(\zeta_{\mathrm{R}}\right)$ is defined in equation (5) and discussed in subsection III.A. Relative adjustment costs between poor and rich countries $(\lambda)$ is defined in equation (7) and discussed in Section III.B. The $\chi$ parameter represents financial market frictions that raise the cost of financial capital in poor countries. 
the firm incurs a fixed cost from investing or disinvesting or if the firm faces asymmetric costs of buying and selling capital (when selling costs are infinite, the firm faces an irreversibility constraint). In either case, a firm must take into account the ex-post possibility of having too much capital when making an ex-ante investment decision, and it will face a "reluctance to invest" (Pindyck and Dixit (1994); Abel and Eberly (1999); Caballero (1999)) that can be thought of as an "irreversibility premium" added to the cost of capital. Based on U.S. data, Chirinko and Schaller (2007) show that the irreversibility premium increases with limited access to resale markets and demand uncertainty, factors that are like to have relatively greater impact in poor countries. Consequently, the irreversibility premium, the cost of capital, and the steadystate MPK all will be relatively higher in poor countries as a result of non-convex and asymmetric adjustment costs.

\section{Summary}

Lucas' question -- “Why Doesn’t Capital Flow from Rich to Poor Countries?” -- remains relevant. Recent advances in measuring the marginal product of capital (MPK) by Caselli and Feyrer (2007) suggest that the MPKs in poor and rich countries are approximately equal and hence that the driving force for equilibrating capital flows vanishes. However, adjustment costs in accumulating capital impact MPK measurement, and they drive a wedge between gross output (relevant for MPK calculations) and net output (published by national income accountants). We develop a revised formula for measuring the MPK that depends on adjustment cost parameters for poor and rich countries. Extant studies are used to generate the relevant range of parameter values. Our computations document that, with the proper technology and a plausible parameterization of adjustment costs, the MPK in poor countries is much higher than the MPK in rich countries. Our preferred estimates indicate that the differential is $100 \%$ to $200 \%$ greater than reported by Caselli and Feyrer. Why capital does not flow among countries to eliminate this MPK differential remains a persistent international puzzle. The calculations and discussion in Section V suggest that adjustment costs may be one factor that deserves further consideration. 


\section{Appendix: Estimates Of The Ratio Of Adjustment Costs to Net Output}

This Appendix details the computations underlying the estimates of $\beta_{R}$ and $\zeta_{R}$ reported in Table I. Our estimates of these two parameters are drawn from seven econometric studies containing precisely estimated adjustment cost parameters (i.e., parameters with standard errors that imply an economically plausible range of values). The most extensive set of studies estimating adjustment cost parameters has been based on US data, and we use these results to estimate $\beta_{\mathrm{R}}$ and $\zeta_{\mathrm{R}}$. Before proceeding to the specifics of the seven studies, we discuss the following elements of the adjustment cost technology common to all studies.

To parameterize the adjustment cost function for rich countries in a parsimonious manner, we adopt the familiar quadratic specification for adjustment costs,

$$
\mathrm{A}[\mathrm{I}, \mathrm{K}]=\left(\beta_{\mathrm{R}} / 2\right) *\left(\mathrm{I}^{2} / \mathrm{K}\right)
$$

and hence the marginal adjustment cost function is as follows,

$$
A_{I}=\beta_{R} *(I / K)
$$

The cross-model comparisons are enhanced by an additional common element -- all models (save the last one) discussed in this subsection can be derived from one general adjustment cost model containing an unobservable shadow price of capital. ${ }^{9}$ The models differ only by the way in which applied researchers relate the unobservable shadow price to observable variables and hence estimate $\beta_{R}$. Given an estimate of $\beta_{R}$, the adjustment costs/net output ratio is computed as follows,

$$
\zeta_{\mathrm{R}} \equiv \mathrm{A}[\mathrm{I}, \mathrm{K}] / \mathrm{Y}^{\mathrm{N}}=\beta_{\mathrm{R}} *(\mathrm{I} / \mathrm{K})_{\mathrm{US}} *\left(\mathrm{I} / \mathrm{Y}^{\mathrm{N}}\right)_{\mathrm{US}} / 2=\beta_{\mathrm{R}} * \Gamma_{\mathrm{US}}
$$

$$
\Gamma_{\mathrm{US}} \equiv(\mathrm{I} / \mathrm{K})_{\mathrm{US}} *\left(\mathrm{I} / \mathrm{Y}^{\mathrm{N}}\right)_{\mathrm{US}} / 2=0.00687
$$

\footnotetext{
${ }^{9}$ See Chirinko (1993, Section III and V.B.) for further discussion of adjustment costs models.
} 
where the investment/capital and investment/net output ratios are evaluated in the last line for the United States with data from Table II.

Hayashi (1982) regresses the investment/capital ratio on stock market Q (adjusted for taxes) using aggregate data. From his equation (30), the coefficient on stock market Q is 0.0423. Given equation (A-2) and the appropriate first-order condition characterizing optimal capital accumulation, the coefficient on stock market $\mathrm{Q}$ can be interpreted as follows:

$0.0423=\beta_{\mathrm{R}}^{-1} \Rightarrow \beta_{\mathrm{R}}=23.641$. Given equation $(\mathrm{A}-3), \zeta_{\mathrm{R}}=0.162$.

Barnett and Sakellaris (1998) regress the investment/capital ratio on stock market Q using firm panel data. From their column 1 in Table 3, the coefficient on stock market Q is 0.020. Given equation (A-2) and the appropriate first-order condition characterizing optimal capital accumulation, the coefficient on stock market Q can be interpreted as follows:

$0.0195=\beta_{\mathrm{R}}^{-1} \Rightarrow \beta_{\mathrm{R}}=51.282$. Given equation $(\mathrm{A}-3), \zeta_{\mathrm{R}}=0.352$. (Their estimates in Table 2 do not reflect tax adjustments and hence are not useful for the comparisons with the five other convex adjustment cost models reviewed here, all of which adjust for taxes.)

It should be noted that Barnett and Sakellaris' preferred model estimates three separate coefficients on stock market $Q$ in a threshold model. We could not use these estimates because we do not have sufficient information to weight these three coefficients to form the single estimate needed for our computation. These three estimates bracket the single coefficient estimates reported above, and hence there is no necessary reason to expect that the estimates of $\beta_{\mathrm{R}}$ and $\zeta_{\mathrm{R}}$ reported in Table I are seriously biased.

Abel and Blanchard (1986) regress the investment/capital ratio on linear projection Q using aggregate data. The linear projection is based on the ex-post equity discount factor, the expost debt discount factor, the after-tax wage bill divided by capital, after-tax output divided by capital, and the rate of wholesale price inflation. The model includes a correction for second degree autocorrelated residuals and the contemporaneous and two lags of linear projection Q. The statistic reported below are the sum of these three coefficients. (It should be noted that the presence of the lagged variables disrupts the structural interpretation of the coefficient estimates, and Abel and Blanchard warn that these estimates should not be interpreted as a structural relation.) From their column 1 in Table Vb, the coefficient on linear projection Q is 0.013 . 
Given equation (A-2) and the appropriate first-order condition characterizing optimal capital accumulation, this coefficient can be interpreted as follows: $0.013=\beta_{\mathrm{R}}^{-1} \Rightarrow$ $\beta_{\mathrm{R}}=76.923$. Given equation $(\mathrm{A}-3), \zeta_{\mathrm{R}}=0.528$.

Gilchrist and Himmelberg (1995) regress the investment/capital ratio on linear projection Q using firm panel data. The linear projection is based on profits and sales both divided by capital. From their column 3 in Table 1, the coefficient on linear projection market Q is 0.183 . Given equation (A-2) and the appropriate first-order condition characterizing optimal capital accumulation, the coefficient on linear projection Q can be interpreted as follows: $0.183=\beta_{\mathrm{R}}^{-1} \Rightarrow \beta_{\mathrm{R}}=5.464$. Given equation $(\mathrm{A}-3), \zeta_{\mathrm{R}}=0.038$.

The panel data estimates of Gilchrist and Himmelberg allow us to assess with comparable data the hypothesis that the relatively more volatile stock market $Q$ is associated with larger estimates of adjustment costs. The coefficient on stock market $\mathrm{Q}$ will tend to be small as it attempts to reconcile highly volatile stock market $Q$ on the right-side of the regression to a less volatile investment/capital ratio on the left-side. Alternatively, measurement error in stock market $\mathrm{Q}$ due to bubbles, noise, or other nonfundamental factors can lower the coefficient on stock market $\mathrm{Q}$. For either reason, the adjustment cost parameter, $\beta_{\mathrm{R}}$, which is the inverse of the coefficient on stock market Q, can be large. The hypothesis is consistent with their empirical results. From their column 2 in Table 1, the coefficient on stock market Q is 0.050 . Given equation (A-2) and the appropriate first-order condition characterizing optimal capital accumulation, this coefficient can be interpreted as follows: $0.050=\beta_{R}^{-1} \Rightarrow \beta_{R}=20.000$. Given equation $(\mathrm{A}-3), \zeta_{\mathrm{R}}=0.137$. This estimate is more than 3.5 times larger than the comparable estimate from their model with linear projection Q.

Shapiro (1986) estimates a system of equations that includes Euler equations for capital, production workers, nonproduction workers, and hours, as well as the wage bill. He reports the following estimate of the marginal reduction of output due to adjustment costs associated with investment, 


$$
\begin{aligned}
\mathrm{A}_{\mathrm{I}} & =\mathrm{g}_{\mathrm{KK}} * \mathrm{Y}^{\mathrm{N}} * \Delta \mathrm{K}, \\
& =0.0014 * 64.0 * 4.8, \\
& =0.430
\end{aligned}
$$

where $\mathrm{g}_{\mathrm{KK}}$ is an estimated parameter from Shapiro's model and its value and the values for $\mathrm{Y}^{\mathrm{N}}$ and $\Delta \mathrm{K}$ are from his page 530. Equation (A-2) allows us to infer $\beta_{R}$,

$$
\begin{gathered}
0.430=\beta_{\mathrm{R}} *(\mathrm{I} / \mathrm{K})_{\mathrm{US}}, \\
\beta_{\mathrm{R}}=5.443
\end{gathered}
$$

where the value of $(\mathrm{I} / \mathrm{K})_{\mathrm{US}}$ is taken from Table II. Given equation $(\mathrm{A}-3), \zeta_{\mathrm{R}}=0.037$.

Chirinko (1995) estimates a system of equations that includes a stock market Q equation, Euler equations for capital and employees, a pricing equation setting marginal revenue equal to marginal cost, and an hours equation based on an inverted production function. These coefficient estimates permit two estimates of $\zeta_{R}$. From the average of his columns 1 to 3 of row 2 in Table 2, the marginal reduction of output due to adjustment costs associated with investment is $A_{I}=0.354$. Equation (A-2) allows us to infer $\beta_{R}$,

$$
\begin{gathered}
0.354=\beta_{\mathrm{R}} *(\mathrm{I} / \mathrm{K})_{\mathrm{US}}, \\
\beta_{\mathrm{R}}=4.481,
\end{gathered}
$$

Given equation (A-3), $\zeta_{\mathrm{R}}=0.031$.

The second approach examines the extent to which adjustment costs for both capital and employment affect MPK measurement. The impact of total adjustment costs on the MPK is represented by $\zeta^{\prime}$ defined in equation (6) as $(\zeta+\phi) / 2$. From the average of columns 1 to 3 of row 3 in his Table 2, $\phi=0.058$. (This estimate is based on the assumption that factor costs equal net output, which is consistent with the assumptions of perfect competition and linear homogeneous technologies used elsewhere in this paper.) The $\zeta$ parameter appearing in equation (6) equals the prior estimate of $\zeta_{R}=0.031$, and $\zeta^{\prime}=0.045=(0.031+0.058) / 2$. 
As an aside, these estimates of $\phi$ (which reflects both employment and capital adjustment costs) and $\zeta$ (which reflects only capital adjustment costs) imply that employment adjustment costs are $87 \%$ as large as capital adjustment costs $(0.87=(\phi-\zeta) / \zeta=$ $(0.058-0.031) / 0.031)$

Cooper and Haltiwanger (2006) estimate a model on plant panel data containing three types of adjustment costs: nonconvexities, costly reversibilities, and convexities. Estimates are obtained by indirect inference that minimizes the weighted difference between actual and simulated moments. Adjustment costs per dollar of investment (AC/I) are computed as follows,

$$
\begin{array}{rlrl}
\mathrm{AC} / \mathrm{I} & =\left((\mathrm{F} * \mathrm{~K}) *\left(1-\pi^{0}\right)\right) / \mathrm{I} & & \text { (nonconvexities) } \\
& +\left(\left(1-\mathrm{p}_{\mathrm{S}}\right) * \mathrm{I}^{*} \pi^{-}\right) / \mathrm{I} & & \text { (costly reversibilities) } \\
& +\left(\left(\gamma^{*} \mathrm{I}^{2} / \mathrm{K}\right) *\left(1-\pi^{0}\right)\right) / \mathrm{I} & \text { (convexities) }
\end{array}
$$

where the $\pi$ 's are the fraction of investment that is negative or zero. F represents fixed costs, $\mathrm{p}_{\mathrm{s}}$ is the selling price (less than or equal to the purchase price of 1.0), and $\gamma$ is equivalent to $\beta_{\mathrm{R}}$ in equation (A-1); these three parameters are estimated. Equation (A-7) ignores interactions among the distribution of investment rates and other plant characteristics and hence is only an approximation of AC/I. From the first three rows of their Table 1 and the first row of their Table 4, equation $(\mathrm{A}-7)$ can be evaluated as follows,

$$
\begin{aligned}
\mathrm{AC} / \mathrm{I} & =((0.039) *(1-0.081)) /(\mathrm{I} / \mathrm{K}) \\
& +((1-0.975) * 0.104) \\
& +((0.049 *(1-0.081)) *(\mathrm{I} / \mathrm{K}) \\
& =0.302
\end{aligned}
$$

An estimate of average adjustment costs relative to net output is obtained as follows,

$$
\zeta " \mathrm{R} \equiv(\mathrm{AC} / \mathrm{I}) *\left(\mathrm{I} / \mathrm{Y}^{\mathrm{N}}\right)=0.302 * 0.174=0.053
$$


To control for endogeneity, Cooper and Haltiwanger replace $\mathrm{K}$ (the capital stock of the plant in a given year) by the average capital stock of the plant. In this case, AC/I rises to 0.395 (fn. 20) and $\zeta " \mathrm{R}=0.069$.

\section{References}

Abel, Andrew B., and Blanchard, Olivier J., "The Present Value of Profits and Cyclical Movements in Investment," Econometrica 54 (March 1986), 249-274.

Abel, Andrew B., and Eberly, Janice E., "The Effects Of Irreversibility And Uncertainty On Capital Accumulation,” Journal Of Monetary Economics_44 (December 1999), 339-378.

Banerjee, Abhijit, and Duflo, Esther, "Growth Theory through the Lens of Development Economics," in Philippe Aghion and Steven Durlauf (eds.), Handbook of Economic Growth, Volume 1A (Amsterdam: Elsevier North-Holland, 2005), (Chapter 7) 473-552.

Barnett, Steven A., and Sakellaris, Plutarchos, "Nonlinear Response Of Firm Investment To Q: Testing A Model Of Convex And Non-Convex Adjustment Costs," Journal Of Monetary Economics 42 (October 1998), 261-288.

Barro, Robert J., and Sala-i-Martin, Xavier, Economic Growth, Second Edition (Cambridge: MIT Press, 2004).

Basu, Susanto, Fernald, John G., and Shapiro, Matthew D., "Productivity Growth in the 1990s: Technology, Utilization, or Adjustment?," Carnegie-Rochester Conference Series on Public Policy 55 (December 2001), 117-166.

Bernanke, Ben, and Gurkaynak, Refet S., "Is Growth Exogenous?: Taking Mankiw, Romer, and Weil Seriously," in Ben Bernanke and Kenneth S. Rogoff (eds.), NBER Macroeconomics Annual 2001 (Cambridge: MIT Press, 2001), 11-57.

Caballero, Ricardo J., “Aggregate Investment,” in John B. Taylor and Michael Woodford (eds.), Handbook Of Macroeconomics, Volume 1B (Amsterdam: Elsevier North-Holland), 1999), 813-862.

Caselli, Francesco, and Feyrer, James, "The Marginal Product of Capital," The Quarterly Journal of Economics 122 (May 2007), 535-568.

Chirinko, Robert S, "Business Fixed Investment: A Critical Survey of Modeling Strategies, Empirical Results, and Policy Implications," Journal of Economic Literature 31 (December 1993), 1875-1911. 
Chirinko, Robert S, "Nonconvexities, Labor Hoarding, Technology Shocks, and Procyclical Productivity: A Structural Econometric Analysis," Journal of Econometrics 66 (March/April 1995), 61-98.

Chirinko, Robert S., and Schaller, Huntley, "The Irreversibility Premium," University of Illinois at Chicago (October 2007).

Cooper, Russell W., and Halitwanger, John C., "On the Nature of Capital Adjustment Costs," Review of Economic Studies 73 (October 2006), 611-633.

Dixit, Avinash K., and Pindyck, Robert S., Investment Under Uncertainty (Princeton: Princeton University Press, 1994).

Djankov, Simeon, La Porta, Rafael, Lopez-de-Silanes, Florencio, and Shleifer, Andrei, “The Regulation of Entry,” The Quarterly Journal of Economics 117 (February 2002), 1-38.

Eisner, Robert and Strotz, Robert H., "Determinants of Business Investment," in Commission on Money and Credit, Impacts of Monetary Policy (Englewood Cliffs, New Jersey: Prentice-Hall, 1963), 60-337.

Gilchrist, Simon, and Himmelberg, Charles P., "Evidence on the Role of Cash Flow for Investment," Journal of Monetary Economics 36 (December 1995), 541-572.

Groth, Charlotta, "Quantifying UK Capital Adjustment Costs,” Economica (May 2008), $310-325$.

Hamermesh, Daniel S., and Pfann, Gerard A., "Adjustment Costs in Factor Demand," Journal of Economic Literature 34 (September 1996), 1264-1292.

Hayashi, Fumio, "Tobin's Marginal q and Average q: A Neoclassical Interpretation," Econometrica 50 (January 1982), 213-224.

Heston, Alan, Summers, Robert, and Aten, Bettina, "Penn World Table: Version 6.1," Center for International Comparisons at the University of Pennsylvania (October 2004).

Hsieh, Chang-Tai, and Klenow, Peter J., "Relative Prices and Relative Prosperity," The American Economic Review 97 (June 2007), 562-585.

Lucas, Robert E., Jr., “Adjustment Costs and the Theory of Supply," The Journal of Political Economy 75 (August 1967, Part 1), 321-334.

Lucas, Robert E., Jr., "Why Doesn't Capital Flow from Rich to Poor Countries?," The American Economic Review 80 (May 1990), 92-96. 
Maccini, Louis J., "Adjustment Costs," in John Eatwell, Murray Milgate, and Peter Newman (eds.), The New Palgrave: A Dictionary of Economics (London: MacMillan Press, 1987), 23-26.

Nickell, Stephen J., The Investment Decisions of Firms (Oxford: Cambridge University Press, 1978). 1987).

Sargent, Thomas J., Macroeconomic Theory, Second Edition (Boston, Academic Press,

Shapiro, Matthew D., "The Dynamic Demand for Labor and Capital," Quarterly Journal of Economics 101 (August 1986), 513-542.

Summers, Robert, and Heston, Alan, "The Penn World Table (Mark 5): An Expanded Set of International Comparisons, 1950-1988," Quarterly Journal of Economics 106 (May 1991), 327-368.

United Nations, Department of Economic and Social Affairs, Statistics Division, A Systems Approach to National Accounts Compilation: A Technical Report (New York: United Nations Publication, 1999).

United Nations, Department of Economic and Social Affairs, Statistics Division, National Accounts: A Practical Introduction (New York: United Nations Publication, 2004).

Woodford, Michael, "Firm-Specific Capital and the New Keynesian Phillips Curve, International Journal of Central Banking 1 (September 2005), 1-46.

World Bank, Where Is the Wealth of Nations? (Washington: The World Bank, 2006).

World Bank, Doing Business (http://www.doingbusiness.org/). 


\section{CESifo Working Paper Series}

for full list see www.cesifo-group.org/wp

(address: Poschingerstr. 5, 81679 Munich, Germany, office@cesifo.de)

2337 Sumon Majumdar and Sharun W. Mukand, The Leader as Catalyst - on Leadership and the Mechanics of Institutional Change, June 2008

2338 Ulrich Hange, Tax Competition, Elastic Labor Supply, and Growth, June 2008

2339 Guy Laroque and Bernard Salanié, Does Fertility Respond to Financial Incentives?, June 2008

2340 Adriano Paggiaro, Enrico Rettore and Ugo Trivellato, The Effect of Extending the Duration of Eligibility in an Italian Labour Market Programme for Dismissed Workers, June 2008

2341 Helmut Seitz, Minimum Standards, Fixed Costs and Taxing Autonomy of Subnational Governments, June 2008

2342 Robert S. Chirinko, Leo de Haan and Elmer Sterken, Asset Price Shocks, Real Expenditures, and Financial Structure: A Multi-Country Analysis, July 2008

2343 Wolfgang Leininger, Evolutionarily Stable Preferences in Contests, July 2008

2344 Hartmut Egger and Udo Kreickemeier, Fairness, Trade, and Inequality, July 2008

2345 Ngo Van Long and Bodhisattva Sengupta, Yardstick Competition, Corruption, and Electoral Incentives, July 2008

2346 Florian Baumann, Employment Protection: The Case of Limited Enforceability, July 2008

2347 Alessandro Balestrino, Cinzia Ciardi and Claudio Mammini, On the Causes and Consequences of Divorce, July 2008

2348 Dirk Schindler and Benjamin Weigert, Insuring Educational Risk: Opportunities versus Income, July 2008

2349 Lammertjan Dam and Ben J. Heijdra, The Environmental and Macroeconomic Effects of Socially Responsible Investment, July 2008

2350 Avner Greif, Contract Enforcement and Institutions among the Maghribi Traders: Refuting Edwards and Ogilvie, July 2008

2351 Helmuth Cremer, Philippe De Donder, Dario Maldonado and Pierre Pestieau, Habit Formation and Labor Supply, July 2008

2352 Francesco Menoncin and Paolo M. Panteghini, The Johansson-Samuelson Theorem in General Equilibrium: A Rebuttal, July 2008 
2353 Michael Kaganovich and Itzhak Zilcha, Alternative Social Security Systems and Growth, July 2008

2354 Keith Blackburn, Kyriakos C. Neanidis and M. Emranul Haque, Corruption, Seigniorage and Growth: Theory and Evidence, July 2008

2355 Edward Castronova, A Test of the Law of Demand in a Virtual World: Exploring the Petri Dish Approach to Social Science, July 2008

2356 Harald Badinger and Peter Egger, GM Estimation of Higher-Order Spatial Autoregressive Processes in Cross-Section Models with Heteroskedastic Disturbances, July 2008

2357 Wolfgang Buchholz and Jan Schumacher, Discounting the Long-Distant Future: A Simple Explanation for the Weitzman-Gollier-Puzzle, July 2008

2358 Luca Anderlini, Leonardo Felli and Alessandro Riboni, Statute Law or Case Law?, July 2008

2359 Guglielmo Maria Caporale, Davide Ciferri and Alessandro Girardi, Are the Baltic Countries Ready to Adopt the Euro? A Generalised Purchasing Power Parity Approach, July 2008

2360 Erkki Koskela and Ronnie Schöb, Outsourcing of Unionized Firms and the Impacts of Labour Market Policy Reforms, July 2008

2361 Francisco Alvarez-Cuadrado and Ngo Van Long, A Permanent Income Version of the Relative Income Hypothesis, July 2008

2362 Gabrielle Demange, Robert Fenge and Silke Uebelmesser, Financing Higher Education and Labor Mobility, July 2008

2363 Alessandra Casarico and Alessandro Sommacal, Labor Income Taxation, Human Capital and Growth: The Role of Child Care, August 2008

2364 Antonis Adam, Manthos D. Delis and Pantelis Kammas, Fiscal Decentralization and Public Sector Efficiency: Evidence from OECD Countries, August 2008

2365 Stefan Voigt, The (Economic) Effects of Lay Participation in Courts - A Cross-Country Analysis, August 2008

2366 Tobias König and Andreas Wagener, (Post-)Materialist Attitudes and the Mix of Capital and Labour Taxation, August 2008

2367 Ximing Wu, Andreas Savvides and Thanasis Stengos, The Global Joint Distribution of Income and Health, August 2008

2368 Alejandro Donado and Klaus Wälde, Trade Unions Go Global!, August 2008

2369 Hans Gersbach and Hans Haller, Exit and Power in General Equilibrium, August 2008 
2370 Jan P.A.M. Jacobs and Jan-Egbert Sturm, The Information Content of KOF Indicators on Swiss Current Account Data Revisions, August 2008

2371 Oliver Hülsewig, Johannes Mayr and Timo Wollmershäuser, Forecasting Euro Area Real GDP: Optimal Pooling of Information, August 2008

2372 Tigran Poghosyan and Jakob de Haan, Determinants of Cross-Border Bank Acquisitions in Transition Economies: A Latent Class Analysis, August 2008

2373 David Anthoff and Richard S.J. Tol, On International Equity Weights and National Decision Making on Climate Change, August 2008

2374 Florian Englmaier and Arno Schmöller, Reserve Price Formation in Online Auctions, August 2008

2375 Karl Farmer, Birgit Friedl and Andreas Rainer, Effects of Unilateral Climate Policy on Terms of Trade, Capital Accumulation, and Welfare in a World Economy, August 2008

2376 Monika Bütler, Stefan Staubli and Maria Grazia Zito, The Role of the Annuity’s Value on the Decision (Not) to Annuitize: Evidence from a Large Policy Change, August 2008

2377 Inmaculada Martínez-Zarzoso, The Impact of Urbanization on $\mathrm{CO}_{2}$ Emissions: Evidence from Developing Countries, August 2008

2378 Brian Roberson and Dmitriy Kvasov, The Non-Constant-Sum Colonel Blotto Game, August 2008

2379 Ian Dew-Becker, How Much Sunlight Does it Take to Disinfect a Boardroom? A Short History of Executive Compensation Regulation, August 2008

2380 Cécile Aubert, Oliver Falck and Stephan Heblich, Subsidizing National Champions: An Evolutionary Perspective, August 2008

2381 Sebastian Buhai, Miguel Portela, Coen Teulings and Aico van Vuuren, Returns to Tenure or Seniority?, August 2008

2382 Erkki Koskela and Jan König, Flexible Outsourcing, Profit Sharing and Equilibrium Unemployment, August 2008

2383 Torberg Falch and Justina AV Fischer, Does a Generous Welfare State Crowd out Student Achievement? Panel Data Evidence from International Student Tests, September 2008

2384 Pedro Gomes and François Pouget, Corporate Tax Competition and the Decline of Public Investment, September 2008

2385 Marko Koethenbuerger, How Do Local Governments Decide on Public Policy in Fiscal Federalism? Tax vs. Expenditure Optimization, September 2008 
2386 Ronald McKinnon and Gunther Schnabl, China's Exchange Rate Impasse and the Weak U.S. Dollar, September 2008

2387 Yan-Leung Cheung, Yin-Wong Cheung and Alan T.K. Wan, A High-Low Model of Daily Stock Price Ranges, September 2008

2388 Louis Eeckhoudt and Harris Schlesinger, Changes in Risk and the Demand for Saving, September 2008

2389 Carsten Hefeker and Blandine Zimmer, Uncertainty and Fiscal Policy in an Asymmetric Monetary Union, September 2008

2390 Jay Pil Choi and Byung-Cheol Kim, Net Neutrality and Investment Incentives, September 2008

2391 Marcel Gérard, Financing Bologna, the Internationally Mobile Students in European Higher Education, September 2008

2392 Annette Alstadsæter and Knut Reidar Wangen, Corporations' Choice of Tax Regime when Transition Costs are Small and Income Shifting Potential is Large, September 2008

2393 António Afonso and Christophe Rault, 3-Step Analysis of Public Finances Sustainability: the Case of the European Union, September 2008

2394 Betsey Stevenson and Justin Wolfers, Economic Growth and Subjective Well-Being: Reassessing the Easterlin Paradox, September 2008

2395 Bernhard Eckwert and Itzhak Zilcha, Private Investment in Higher Education: Comparing Alternative Funding Schemes, September 2008

2396 Øystein Foros, Hans Jarle Kind and Jan Yngve Sand, Slotting Allowances and Manufacturers’ Retail Sales Effort, September 2008

2397 Mohammad Reza Farzanegan, Illegal Trade in the Iranian Economy: Evidence from a Structural Model, September 2008

2398 Olivier Bos, Charity Auctions for the Happy Few, September 2008

2399 Robert S. Chirinko and Debdulal Mallick, The Marginal Product of Capital: A Persistent International Puzzle, September 2008 